\title{
Influence of antral follicle size on oocyte characteristics and embryo development in the bovine
}

\author{
Anne-Sophie Lequarre ${ }^{\mathrm{a}, *}$, Céline Vigneron ${ }^{\mathrm{b}}$, Fabrice Ribaucour ${ }^{\mathrm{a}}$, \\ Peter Holm ${ }^{\mathrm{c}}$, Isabelle Donnay ${ }^{\mathrm{a}}$, Rozenn Dalbiès-Tran ${ }^{\mathrm{b}}$, \\ Henrik Callesen ${ }^{\mathrm{c}}$, Pascal Mermillod ${ }^{\mathrm{b}}$ \\ anstitut des Sciences de la Vie, Unité des Sciences Vétérinaires, Université Catholique de Louvain (UCL), \\ Place Croix du Sud 5 Bte 10, B-1348 Louvain-la-Neuve, Belgium \\ ${ }^{\mathrm{b}}$ Institut national de la Recherche Agronomique (INRA), Centre de Recherches de Tours, \\ Station de Physiologie de la Reproduction, F-37380 Nouzilly, France \\ ${ }^{\mathrm{c}}$ Department of Animal Breeding and Genetics, Section of Reproductive Biology, Danish Institute of \\ Agricultural Sciences (DIAS), DK-8830 Tjele, Denmark
}

Received 19 January 2004; received in revised form 7 May 2004; accepted 12 May 2004

\begin{abstract}
The developmental competence of bovine oocytes isolated from antral follicles of different sizes was assessed in three European laboratories (Belgium, UCL; Denmark, DIAS; France, INRA). Using the same protocol for in vitro production of embryos, the oocytes isolated from follicles with a diameter $\geq 6 \mathrm{~mm}$ always gave a higher blastocyst rate than oocytes from follicles $<4 \mathrm{~mm}$ (UCL: $42 \%$ versus $14 \%$, DIAS: $50 \%$ versus $35 \%$, INRA: $39 \%$ versus $22 \% ; P<0.05$ ). Blastocyst cell number was not affected by follicle size. Several parameters were investigated for these oocytes. The energy metabolism of cumulus-oocyte-complexes and of denuded oocytes was assessed by the oxygen and pyruvate uptake and by lactate release both at the beginning and the end of the maturation. No effect of follicle size could be detected but lactate release increased after maturation. The global profile of transcripts, the pattern of protein neosynthesis and the kinetics of meiosis resumption were not affected by follicle size. The developmental kinetics of derived embryos was also analysed. Whatever the follicle size, viable embryos had a shorter first and third embryonic cell cycle. Among the viable embryos, the size of the follicle interfered with the fourth cell cycle duration. A higher percentage of blastocysts issued from large follicle presented a short fourth cell cycle $(9 \mathrm{~h})(35 \%$ versus $6 \% ; P<$ 0.05). Beside, blastocysts derived from small follicles had a delayed cavitation and expansion. Thereby, a higher developmental competence for oocytes from follicle $\geq 6 \mathrm{~mm}$ versus $<4 \mathrm{~mm}$ was
\end{abstract}

\footnotetext{
* Corresponding author. Tel.: +32-10473701; fax: +32-10473717.

E-mail address: lequarre@vete.ucl.ac.be (A.-S. Lequarre).
} 
demonstrated in three laboratories although no differences could be displayed directly at the oocyte level.

(C) 2004 Elsevier Inc. All rights reserved.

Keywords: Oocyte; Follicle size; Meiotic resumption; Transcriptome; Protein synthesis; Developmental potential; Embryo kinetics

\section{Introduction}

Most mammalian oocytes present in the ovaries at birth will be lost during the physiological process of atresia as only few will reach ovulation. In cattle, oocytes isolated from 3 to $8 \mathrm{~mm}$ antral follicles can be rescued by the in vitro embryo production techniques. However, many of the oocytes collected that way will go through maturation but will subsequently fail to develop into viable embryos. Indeed, only $30-40 \%$ of the zygotes obtained after in vitro maturation and fertilization will reach the blastocyst stage in culture [1]. It has been demonstrated that this low level of development is mostly due to oocyte deficiency before and/or during the in vitro maturation process [2] as oocytes collected by follicular aspiration from both slaughterhouse ovaries or by ovum pick up (OPU) are quite heterogeneous.

Until now, no convenient markers of oocyte developmental competence have been described. Non invasive criteria for oocyte selection can rely on the morphology of the ovary [3,4] and its ovarian phase [5]. The size of the follicle [6-8], its level of atresia $[9,10]$ and the progesterone concentration of the follicular fluid [11] are also good indicators. Finally, oocyte developmental competence is also correlated with the morphology of the cumulus-oocyte-complex (COC) $[8,12]$ and morphology of the corona radiata [13].

In this study, three laboratories have gathered their efforts and technical competence to identify other parameters describing the quality of bovine oocytes. The focus has first been on follicular size, i.e. diameter, and the oocytes recovered were assessed based on their ability to undergo in vitro maturation and embryo development. Once follicle sizes containing oocytes characterised by different developmental competence within each laboratory were determined, the following parameters were analysed:

(1) The energy metabolism at the beginning and at the end of the maturation period, evaluated by the uptake of oxygen and pyruvate and the release of lactate. Indeed, such parameters, in combination with others, have been used as quality markers for in vitro produced embryos [14].

(2) The transcriptome in immature oocytes by cDNA array screening.

(3) The protein synthesis pattern before and after in vitro maturation. In fact important changes of protein pattern occur during maturation and morphological features of COC have been associated with different patterns of protein synthesis $[15,16]$.

(4) The kinetics of nuclear maturation. The time of extrusion of the first polar body was associated with variable subsequent embryonic development [17].

(5) The kinetics of development of embryos according to follicle size of the oocyte from which they were derived. Cleavage schedule can be an indicator of developmental 
competence [18-21] furthermore it is a non-invasive technique easy to perform without interfering with the viability of the embryo.

\section{Materials and methods}

All chemicals originated from Sigma Chemical Co. (St. Louis, MO, USA) unless otherwise stated.

\subsection{Oocytes collection}

In each laboratory, ovaries were collected from slaughtered cows at local abattoirs. Follicles were dissected with scissors at room temperature, measured under a stereomicroscope and separated according to their diameter into three groups: (1) small follicles: $<4 \mathrm{~mm}$ (the lowest follicle size was $2 \mathrm{~mm}$ but most follicles were around $3 \mathrm{~mm}$ ), (2) middle size follicles: $4-5 \mathrm{~mm}$, and (3) large follicles: $\geq 6 \mathrm{~mm}$ (the largest follicles could reach $10 \mathrm{~mm}$ but most of them were between 6 and $8 \mathrm{~mm}$ ). COCs were liberated by carefully rupturing the follicles. Only healthy-looking COCs (three or more dense layers of cumulus cells and evenly granulated cytoplasm) were kept for in vitro embryo production techniques and analysis.

\subsection{In vitro embryo production}

For in vitro production of bovine embryos, the three laboratories used the same protocol, with a few details differing from one lab to another (Table 1). Briefly, COCs were matured for $24 \mathrm{~h}$ in tissue culture medium 199 (TCM-199) supplemented with $10 \mathrm{ng} / \mathrm{ml}$ epidermal growth factor (EGF) at $39{ }^{\circ} \mathrm{C}$ under $5 \% \mathrm{CO}_{2}$ in humidified air. COCs were then washed in TCM-199 and transferred to fertilization medium (TALP-low bicarbonate $(2 \mathrm{mg} / \mathrm{ml})$ Tyrode's medium containing $6 \mathrm{mg} / \mathrm{ml}$ fatty acid-free albumin fraction $\mathrm{V}, 4 \mathrm{mg} / \mathrm{ml}$ sodium lactate, $0.11 \mathrm{mg} / \mathrm{ml}$ sodium pyruvate and $10 \mu \mathrm{g} / \mathrm{ml}$ heparin-sodium salt). The breed of the semen used in DIAS and UCL laboratories was the same than for ovaries, at INRA the semen was from a Belgian-blue bull. After separation on a Percoll discontinuous density gradient (45-90\%) spermatozoa were added to the fertilization well at a final concentration of $2 \times 10^{6} \mathrm{ml}^{-1}$. After $18-22 \mathrm{~h}$ of fertilization, cumulus cells were removed and $25-30$

Table 1

Variations of bovine IVP protocols between research teams

\begin{tabular}{llll}
\hline Parameters & \multicolumn{2}{l}{ Laboratory } & \\
\cline { 2 - 4 } & DIAS & INRA & UCL \\
\hline Cow breed & Holstein-friesian & Mixed breed & Belgian-blue \\
Maturation & - & - & 0.4 mM pyruvate \\
Fertilization medium & No BSA but $1 \%$ cattle serum - & - \\
Fertilization length & $22 \mathrm{~h}$ & $22 \mathrm{~h}$ & $18 \mathrm{~h}$ \\
Denuding zygotes & $1 \mathrm{~min}$ vortexing & $2 \mathrm{~min}$ vortexing & Repeated pipeting \\
\hline
\end{tabular}


denuded zygotes were cultured in $30 \mu \mathrm{l}$ droplets of synthetic oviduct fluid (SOF) modified as described [22] and containing $2.8 \mathrm{mM}$ myo-inositol, $0.3 \mathrm{mM} \mathrm{Na}$ citrate and $5 \%$ FCS. Culture was performed in a humidified atmosphere of $5 \% \mathrm{CO}_{2}, 5 \% \mathrm{O}_{2}$ and $90 \% \mathrm{~N}_{2}$ for 7 days. At the end of the culture period all blastocysts were fixed with ethanol and stained with bisbenzimide (Hoechst 33342, Calbiochem) to count the number of nuclei.

\subsection{Metabolism}

This work was realised by the UCL team.

\subsubsection{Oxygen uptake by COCS and denuded oocytes}

Oxygen uptake was evaluated as described by [23]. Briefly, pools of two COCs or pools of 10 denuded oocytes isolated from two follicle sizes $(<4 \mathrm{~mm}$ or $\geq 6 \mathrm{~mm}$ ) were incubated in $2 \mu \mathrm{l}$ Hepes-buffered maturation medium in sealed PCR pipettes and in contact with $1 \mu \mathrm{l}$ paraffin oil containing $1 \mathrm{mM}$ pyrene, a compound whose fluorescence emission is inversely correlated with the oxygen concentration. A $0 \%$ oxygen control was prepared by substituting the maturation medium with $1 \mathrm{mg} / \mathrm{ml}$ baker's yeast in $60 \mathrm{mmol} / \mathrm{L}$ D-glucose. This was allowed to equilibrate overnight before use. The air-saturated control was prepared by omitting embryos from the medium. Fluorescence was measured at the oil phase every $20 \mathrm{~min}$ for $3 \mathrm{~h}$. Oxygen uptake was then calculated using a computer assisted program [23]. At the end of the incubation period, the pipettes were unsealed and the oocytes recovered. COCs were collected in $200 \mu \mathrm{l}$ of phosphate-buffered saline solution (PBS) and denuded by pipeting. Oocytes were fixed and stained for evaluation of their maturation stage. The number of cumulus cells per group of two COCs was evaluated using an hemocytometer. Oocytes and COCs from both follicle classes were analysed at the beginning ( $0-4 \mathrm{~h})$ and at the end (20-24 h) of the maturation period.

\subsubsection{Pyruvate uptake and lactate release}

The uptake of pyruvate and release of lactate by denuded oocytes were evaluated microfluorimetrically [24] by measuring the concentration of pyruvate and lactate in spent culture drops. Briefly, pools of 10 denuded oocytes were incubated for $4 \mathrm{~h}$ in $1 \mu \mathrm{l}$ drops of culture medium $(199+10 \mathrm{ng} / \mathrm{ml} \mathrm{EGF}+0.4 \mathrm{mM}$ pyruvate). After incubation, oocytes were removed and stained to assess their maturation stage. The culture dishes were sealed and frozen until further analysis. The culture medium of oocytes from both follicle classes was analysed at the beginning $(0-4 \mathrm{~h})$ and at the end $(20-24 \mathrm{~h})$ of the maturation period.

\subsection{Protein synthesis}

This work was performed by the INRA team.

COCs from three different follicle sizes were radiolabeled just after collection or matured for $24 \mathrm{~h}$ and subsequently radiolabeled for $3 \mathrm{~h}$ at $39{ }^{\circ} \mathrm{C}$ in PBS containing $1 \mu \mathrm{Ci} /$ $\mathrm{ml}\left({ }^{35} \mathrm{~S}\right)$ methionine (Express Protein Labeling Mix, NEN). After labeling, oocytes were denuded by repeated pipeting and washed three times in PBS with $0.1 \%$ poly-vinylpyrrolidone. Oocytes were lysed by groups of 10 in $15 \mu \mathrm{l}$ of buffer [25] followed by heating at $100{ }^{\circ} \mathrm{C}$ for $3 \mathrm{~min}$ and stored at $-20{ }^{\circ} \mathrm{C}$ until electrophoresis. Thawed samples were 
centrifuged and the radiolabeled proteins resolved by SDS-PAGE. Gels were treated with Amplify (Amersham Biosciences, Orsay, France) for $30 \mathrm{~min}$, dried and exposed on film (Hyperfilm MP, Amersham Pharmacia Bioth, Little Chalfont, UK) for 7 days at room temperature. Two replicates were carried out for each follicle size.

\subsection{Evaluation of nuclear maturation status}

This work was realised by the DIAS team.

At $0,3,6,9,12,15,18$ and $21 \mathrm{~h}$ after the start of the in vitro maturation process, $10-15$ oocytes from each follicle sizes were denuded, mounted on slides and fixed with acetic alcohol (1:3 acetic acid: ethanol) for $24 \mathrm{~h}$. They were stained with $1 \%$ aceto-orcein to evaluate the stage of meiotic maturation. Based on their nucleus status, oocytes were classified as germinal vesicle 1 or $2(\mathrm{GV} 1, \mathrm{GV} 2)$, diakinese 1 or 2 (D1, D2), metaphase 1 (M1), anaphase1 (A1), telophase 1 (T1), metaphase 2 (M2) or undefined (?) as described [26].

\subsection{Gene expression profile}

This work was realised by the INRA team.

\subsubsection{Oocyte collection and RNA isolation}

Oocytes isolated from different follicle sizes were mechanically denuded and washed several times. Absence of cumulus cells was carefully checked under a stereomicroscope. Originating from two independent ovaries collections, 41 and 7 oocytes from large (L) follicles $\geq 6 \mathrm{~mm}$ (respective follicle diameter $6.9 \pm 0.3$ and $7.3 \pm 0.4 \mathrm{~mm}$ (mean \pm S.D.)) and 32 and 10 oocytes from small $(\mathrm{S})$ follicles $<4 \mathrm{~mm}$ (follicle diameter $3.7 \pm 0.3$ and 3.6 $\pm 0.3 \mathrm{~mm}$ ) were collected and frozen at $-80{ }^{\circ} \mathrm{C}$ until RNA extraction. Total RNA from the four groups was isolated in parallel using the Tripure Isolation Reagent (Roche Diagnostics, France) following the manufacturer's instructions.

\subsubsection{Probe generation}

The 32P-labeled probes were generated as previously described [27]. Only a fraction (32/41) of the RNA from the first pool was used as a substrate in the reverse transcription, therefore the corresponding probe was indeed synthesised from the RNA content of 32 oocytes (probe L32). For the other three samples, the whole RNA was used (probes L7, S32, S10). Briefly, the RNA from each oocyte pool was reverse-transcribed using the SmartII and CDS primers, and the resulting cDNA purified on Nucleospin columns (SuperSmart PCR cDNA synthesis kit, BD Biosciences-Ozyme, France). Actual cDNA synthesis and absence of genomic DNA contamination was confirmed by subjecting aliquots of each reaction mix to amplification by PCR with specific primers designed to hybridise within two exons separated by a short intron within the $\beta$-actin gene. Each cDNA population was then amplified using the Atlas Smart probe amplification kit (BD Biosciences-Ozyme). The optimal number of PCR cycles to be used for probe preparation was found to be 17 for the L32, S32 and S10 probes, 20 cycles for the L7 probe. Amplified cDNA were purified on Nucleospin columns, precipitated in the presence of sodium 
acetate, resuspended, and the concentration estimated based on optical density. Two hundred and fifty to $500 \mathrm{ng}$ from each cDNA mix was used as a substrate for random prime labeling (Atlas Smart probe amplification kit, BD Biosciences-Ozyme) in the presence of $[\alpha-32 P]-d A T P$ (Perkin-Elmer Life Sciences). Finally, radiolabeled probes were purified as recommended by the manufacturer. Radioactivity was estimated by scintillation counting.

\subsubsection{Array hybridisation}

Broad-scale expression profiling was performed using the Atlas human 1.2 cDNA expression array (BD Biosciences-Ozyme). These nylon membranes are spotted with 1176 human cDNA fragments from known genes, between 200 and 600 base pair in length. Spots are arrayed onto six regions according to gene function: (A) oncogenes, tumor suppressors, cell cycle regulators, (B) transporters, signal transduction, (C) GDP/GTP exchangers, GTPase stimulators and inhibitors, apoptosis, (D) transcription factors, cell signaling and extracellular communication, (E) cell surface antigens, cell adhesion, receptors, and (F) stress response, cell-cell communication. In addition, cDNA fragments from selected housekeeping genes, human genomic DNA, phage and plasmidic DNA are spotted as positive and negative controls. The manufacturer's instructions were followed with minor modifications. After heat denaturation, probes were hybridised at $68{ }^{\circ} \mathrm{C}$ overnight to four identical membranes. After several washes in $2 \times \mathrm{SSC}, 1 \% \mathrm{SDS}$, the membranes were exposed to a Phosphor storage screen (Amersham Biosciences) for 5 days before image acquisition by a Storm 840 (Amersham Biosciences).

\subsubsection{Gene expression analysis}

For quantitative analysis the ImageQuant software (Amersham Biosciences) was used. Intensity corrected for the local average background was calculated for all spots. To correct for differences between the membranes in the global hybridisation intensity, the sum of the intensities of the spots within the considered region (cDNAs are arranged in the array in seven regions labeled $\mathrm{A}-\mathrm{G}$ ) was normalized between the membranes (intra-class normalization). For a gene to be further considered, the corresponding spot had to meet several criteria: (i) detection on both replicates of one (at least) follicle class, (ii) normalized intensity within a $2 \times$ range between the replicates of a follicle class. For such spots, the average intensity in large and medium follicle was calculated. Total intensity within each region was again normalized, this time between the follicle classes (inter-class normalization), and normalized average values were then compared.

\subsection{Cinematographic analysis}

This analysis was performed by the UCL team on oocytes from two follicle sizes $(<4$ and $\geq 6 \mathrm{~mm}$ ). To perform time-lapse cinematography, embryos were incubated in a culture dish placed in a small chamber on the plate of an inverted microscope (Zeiss). The chamber was flushed with a humidified and warmed gas mixture consisting of $5 \% \mathrm{CO}_{2}, 5 \% \mathrm{O}_{2}, 90 \% \mathrm{~N}_{2}$. To maintain a constant temperature of $39{ }^{\circ} \mathrm{C}$, a Plexiglas box was adapted to fit onto the microscope and connected to a heating system controlled by a temperature probe. The recording equipment consisted of a colour video camera KY-F55E from JVC and two computers. The first computer synchronises the lighting of the lamp and the shooting. The 
second digitises and records the frames with the programme Perception Video Recorder (Alpha M). One image was recorded every $180 \mathrm{~s}$.

Development of the embryos was filmed from the zygote stage (18 hpi) for 7 days under a $40 \times$ magnification. Movies were analysed by detecting, for each embryo, the time of appearance of two-cell, three-cell, five-cell, nine-cell, morula, blastocyst and hatched blastocyst stages. Only the embryos visible in the camera field throughout the culture period were examined. As a control embryos of the same origin were simultaneously cultured in usual incubator.

\subsection{Statistical analysis}

Statistical analysis of cleavage and blastocyst rates as well as blastocyst cell number according to follicle size was performed using one-way ANOVA. For metabolism, ANOVA2 (SYSTAT software; Evanston, Illinois) was used (follicle size and replications as fixed factors). The kinetics of nuclear maturation was analysed using Proc Genmod from SAS [28]. The effect of follicle size on developmental stages reached by embryos stopping development and the effect of follicle size on the proportion of embryos with a short fourth cell cycle were both evaluated using a Chi-square test. Data on kinetics of embryo development were analysed with a mixed linear model using viability and follicle size as fixed factors and experiment (movies) as a random factor. $P$ values less than 0.05 were considered significant.

\section{Results}

\subsection{Developmental potential}

Results obtained in each laboratory are presented together in Table 2. For the DIAS team, there was no difference in cleavage rate according to follicle size but a higher percentage of blastocysts was obtained when oocytes were recovered from follicles $\geq 6 \mathrm{~mm}$ versus oocytes from follicles $<4 \mathrm{~mm}$. For the INRA team, both higher cleavage and blastocyst rates were obtained for oocytes recovered from follicles $\geq 4 \mathrm{~mm}$ versus oocytes from follicles $<4 \mathrm{~mm}$. For the UCL team, higher cleavage and blastocyst rates were only obtained when oocytes were recovered from follicles $\geq 6 \mathrm{~mm}$ versus oocytes from the two other follicle sizes. In fact, oocytes emerging from middle size follicles (4-5 mm) had a different developmental potential according to the laboratory. But, in all laboratories, oocytes coming from follicles $<4 \mathrm{~mm}$ had a lower developmental potential than oocytes coming from follicles $\geq 6 \mathrm{~mm}$ Although blastocyst rate differs according to follicle size, there was no difference in the cell number of day 8 blastocyst as illustrated in Table 3 .

\subsection{Metabolism}

\subsubsection{Oxygen uptake by COCs and denuded oocytes}

Oxygen uptake was first evaluated on COCs, and then the number of cumulus cells was evaluated in order to express these values in function of cell number. A significant higher 
Table 2

Embryonic development (mean $\% \pm$ S.D.) for oocytes derived from different follicle sizes comparison between the three laboratories

\begin{tabular}{|c|c|c|c|c|c|c|}
\hline \multirow[t]{2}{*}{ Laboratory } & \multicolumn{3}{|c|}{ Cleavage rate (D3 pi) (n replicates; total oocytes) } & \multicolumn{3}{|c|}{ Blastocyst rate (D7 pi) ( $n$ replicates; total oocytes) } \\
\hline & $<4 \mathrm{~mm}$ & $4-5 \mathrm{~mm}$ & $\geq 6 \mathrm{~mm}$ & $<4 \mathrm{~mm}$ & $4-5 \mathrm{~mm}$ & $\geq 6 \mathrm{~mm}$ \\
\hline DIAS & $80 \pm 9^{\mathrm{a}}(7 ; 187)$ & $82 \pm 8^{\mathrm{a}}(7 ; 174)$ & $84 \pm 8^{\mathrm{a}}(7 ; 89)$ & $35 \pm 14^{\mathrm{a}}(7 ; 187)$ & $45 \pm 11^{\mathrm{a}, \mathrm{b}}(7 ; 89)$ & $50 \pm 7^{\mathrm{b}}(7 ; 174)$ \\
\hline INRA & $72 \pm 9^{\mathrm{a}}(5 ; 203)$ & $84 \pm 6^{\mathrm{b}}(5 ; 260)$ & $89 \pm 4^{\mathrm{b}}(5 ; 109)$ & $22 \pm 1^{\mathrm{a}}(5 ; 203)$ & $31 \pm 6^{\mathrm{b}}(5 ; 260)$ & $39 \pm 16^{\mathrm{b}}(5 ; 109)$ \\
\hline UCL & $53 \pm 10^{a}(8 ; 125)$ & $54 \pm 10^{\mathrm{a}}(9 ; 279)$ & $71 \pm 12^{\mathrm{b}}(9 ; 89)$ & $14 \pm 8^{\mathrm{a}}(10 ; 166)$ & $17 \pm 26^{\mathrm{a}}(11 ; 327)$ & $42 \pm 23^{\mathrm{b}}(11 ; 120)$ \\
\hline
\end{tabular}


Table 3

Average cell number (mean \pm S.D.) for day 8 blastocysts according to follicle size in two laboratories: DIAS (Denmark) and INRA (France)

\begin{tabular}{lrc}
\hline Follicle size $(\mathrm{mm})$ & \multicolumn{1}{c}{ DIAS } & \multicolumn{1}{l}{ INRA } \\
\hline$<4$ & $95 \pm 30(n=48)$ & $86 \pm 42(n=32)$ \\
$4-5$ & $102 \pm 45(n=57)$ & $105 \pm 51(n=101)$ \\
$\geq 6$ & $92 \pm 30(n=29)$ & $92 \pm 43(n=47)$ \\
\hline
\end{tabular}

number of cumulus cells was found for COCs coming from large follicles compared with those arising from small follicles (beginning of maturation: $9885 \pm 1866$ versus $7000 \pm$ 1184; end of maturation: $23400 \pm 8065$ versus $5857 \pm 903$; eight replicates; ANOVA2, $P=0.02$ ). When oxygen uptake was expressed per COC, no effect of the size of the follicle or the stage of maturation was observed. When we took into account the cumulus cell number by dividing the oxygen uptake with the number of cumulus cells in each pipette, a tendency for a higher oxygen uptake was observed in COCs from small follicles (ANOVA2, $P=0.09$ ). However, when evaluating oxygen uptake by oocytes denuded before evaluation of metabolic activity, no difference could be detected between follicle classes or maturation stages (Table 4).

\subsubsection{Pyruvate uptake and lactate release}

Attempts to measure glucose uptake by denuded oocytes were unsuccessful. This might be due to the high concentration in glucose $(5.5 \mathrm{mM})$ in the maturation medium, or to the removal of the cumulus cells. Pyruvate uptake was not affected by follicle size or by the stage of maturation (Table 5). Lactate release was increased at the end of the maturation period (Table 5). However, follicle size did not seem to influence this parameter.

\subsection{Gene expression profile}

Out of 1176 genes represented on the membrane (not considering control housekeeping genes), 358 spots met the required criteria for quantitative analysis (see Section 2). After normalization for the sum of intensities within each region, the ratio of transcripts relative abundance in oocytes from large follicles to transcripts relative abundance in oocytes from small follicles was $1.01 \pm 0.30$ (mean \pm S.D.). No gene displayed a relative variation over three fold between follicle categories (Fig. 1).

Table 4

Oxygen uptake (mean \pm S.E.M.) by cumulus-oocyte-complex (COC), cumulus cells and denuded oocyte depending on the size of the follicle

\begin{tabular}{lccll}
\hline $\begin{array}{l}\text { Follicle } \\
\text { size }(\mathrm{mm})\end{array}$ & $\begin{array}{l}\text { Maturation } \\
\text { time }(\mathrm{h})\end{array}$ & $\begin{array}{l}\text { Oxygen } \\
\text { uptake/COC }(\mathrm{nl} / \mathrm{h})\end{array}$ & $\begin{array}{l}\text { Oxygen uptake/ } \\
\text { cumulus cell }(\mathrm{pl} / \mathrm{h})\end{array}$ & $\begin{array}{l}\text { Oxygen uptake/ } \\
\text { denuded oocyte }(\mathrm{pl} / \mathrm{h})\end{array}$ \\
\hline$<4$ & $0-4$ & $9.6 \pm 1.7(n=8)$ & $1.84 \pm 0.55(n=8)$ & $0.49 \pm 0.036(n=5)$ \\
$\geq 6$ & $0-4$ & $7.9 \pm 1.2(n=7)$ & $1.22 \pm 0.49(n=7)$ & $0.55 \pm 0.05(n=5)$ \\
$<4$ & $20-24$ & $9.4 \pm 11.6(n=7)$ & $2.12 \pm 0.68(n=7)$ & $0.63 \pm 0.10(n=5)$ \\
$\geq 6$ & $20-24$ & $10.5 \pm 1.1(n=7)$ & $0.92 \pm 0.28(n=7)$ & $0.48 \pm 0.08(n=5)$ \\
\hline
\end{tabular}

$n$ : number of replicates; ANOVA2, $P>0.05$. 
Table 5

Pyruvate uptake and lactate release (mean \pm S.E.M.) by pools of 10 denuded oocytes before and after in vitro maturation - comparison between small and large follicles

\begin{tabular}{lclll}
\hline $\begin{array}{l}\text { Follicle } \\
\text { size }(\mathrm{mm})\end{array}$ & $\begin{array}{l}\text { Maturation } \\
\text { time }(\mathrm{h})\end{array}$ & Replicates $N$ & $\begin{array}{l}\text { Pyruvate uptake } \\
(\mathrm{pmol} / \text { oocyte/h) }\end{array}$ & $\begin{array}{l}\text { Lactate release } \\
(\mathrm{pmol} / \text { oocyte/h) }\end{array}$ \\
\hline$<4$ & $0-4$ & 7 & $5.9 \pm 1.3$ & $-0.25 \pm 0.31^{\mathrm{a}}$ \\
$\geq 6$ & $0-4$ & 6 & $6.1 \pm 0.9$ & $-0.95 \pm 1.5^{\mathrm{a}}$ \\
$<4$ & $20-24$ & 7 & $3.7 \pm 1.2$ & $-5.66 \pm 2.75^{\mathrm{b}}$ \\
$\geq 6$ & $20-24$ & 6 & $4.7 \pm 0.7$ & $-5.10 \pm 2.75^{\mathrm{b}}$ \\
\hline
\end{tabular}

$\stackrel{\mathrm{a}, \mathrm{b}}{\mathrm{Data}}$ with different superscripts are significantly different (ANOVA2, $P<0.05$ ).

\subsection{Protein synthesis}

A typical gel is presented in Fig. 2. Before maturation the same profile for protein neosynthesis was observed for all oocytes irrespective of the follicle size. After maturation protein profiles exhibited numerous changes but there was once again no difference between follicle sizes. However, the labeling intensity appeared stronger for oocytes from large follicles.

\subsection{Kinetics of maturation}

Results for oocytes from the three follicle sizes are presented in Fig. 3. No difference in the kinetics of maturation could be demonstrated between follicle sizes.

\subsection{Developmental kinetics}

\subsubsection{Developmental potential}

As expected, the developmental potential of oocytes isolated from large follicles $(\geq 6 \mathrm{~mm})$ was also higher during the cinematography study. In order to study a similar

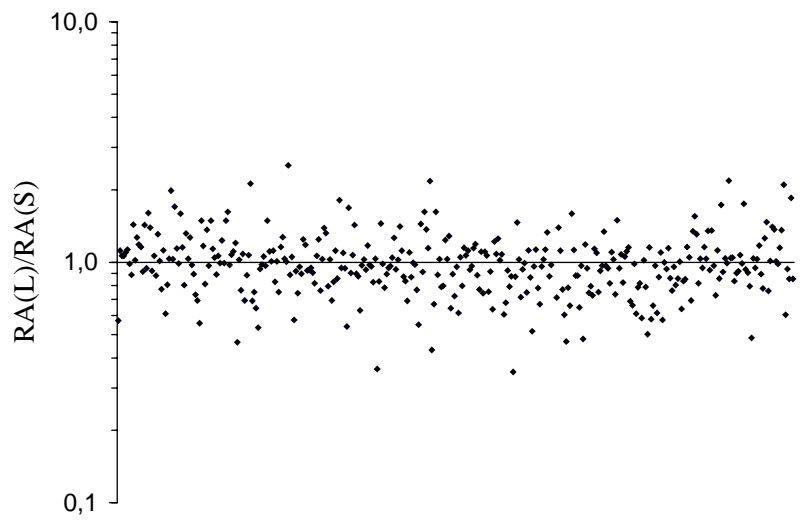

Fig. 1. Ratio of the relative abundances of transcripts in oocytes from large (RA(L)) to small (RA(S)) follicle. Each dot corresponds to a transcript. 


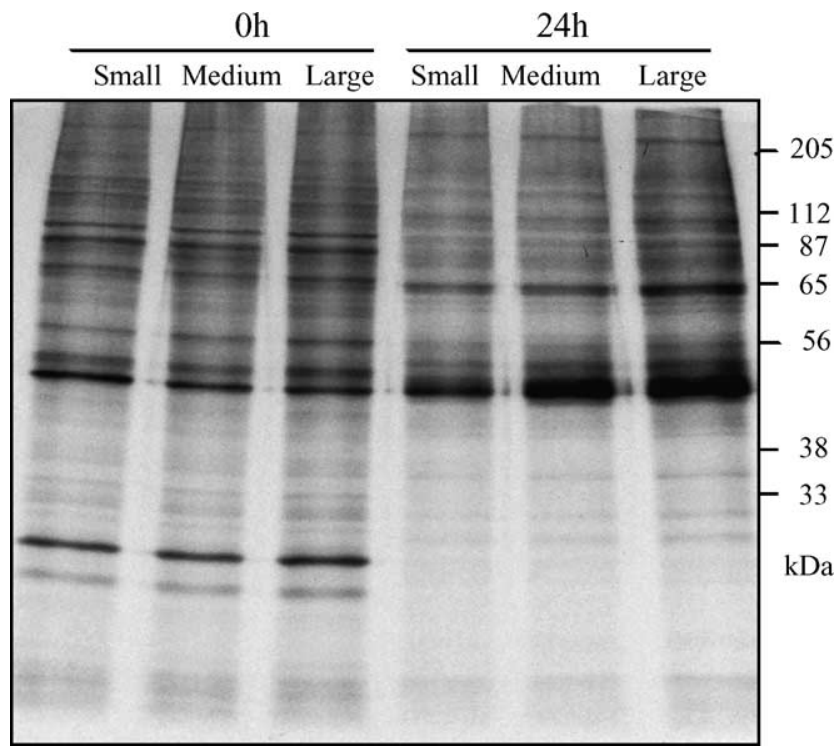

Fig. 2. Neosynthesis protein profile of oocytes from three sizes of follicle. Small: $<4 \mathrm{~mm}$; medium: 4-5 mm; large: $\geq 6 \mathrm{~mm}$ at the beginning $(0 \mathrm{~h})$ and at the end $(24 \mathrm{~h})$ of in vitro maturation. Each lane represents 10 oocytes. Molecular weights expected are indicated.

number of blastocyst emerging from both follicle sizes, the kinetics data had to be gathered from three movies for embryos coming from large follicles (66 zygotes) but from eight movies for embryos coming from small follicles (147 zygotes). Of the zygotes isolated from large follicles $85 \%$ cleaved versus $69 \%$ from small follicles

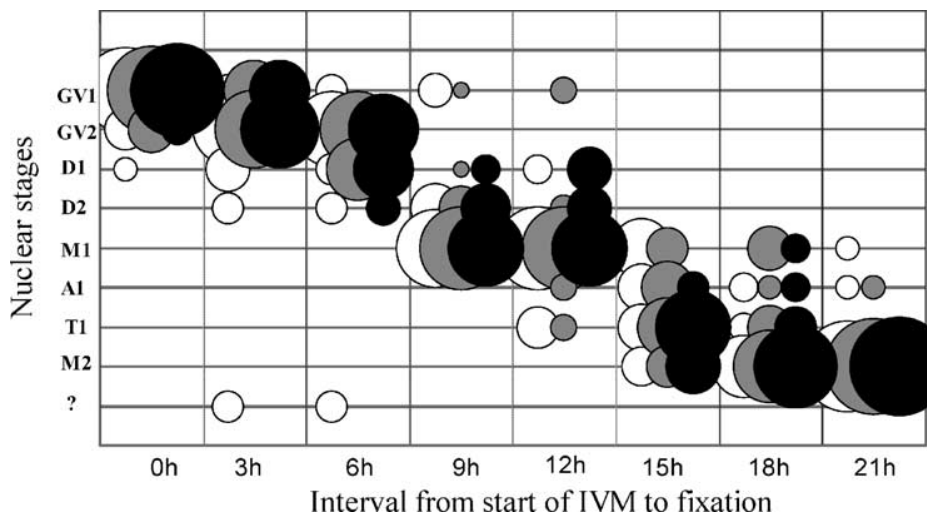

Fig. 3. Nuclear stages of oocytes isolated from different follicular sizes and observed at variable times after the start of in vitro maturation. Nuclear stages observed: germinal vesicles 1 and 2 (GV1, GV2); diakinese 1 and 2 (D1, D2); metaphase 1 (M1), anaphase 1 (A1), telophase 1 (T1), metaphase 2 (M2) and undefined (?). At each time, 10-15 oocytes from the three follicle sizes were analysed. White bubbles represent oocytes from follicles $<4 \mathrm{~mm}$; grey bubbles: oocytes from follicles from 4 to $5 \mathrm{~mm}$; and black bubbles: oocytes from follicles $\geq 6 \mathrm{~mm}$. The diameter of each bubble is proportional to the number of oocytes observed at the corresponding stage. 


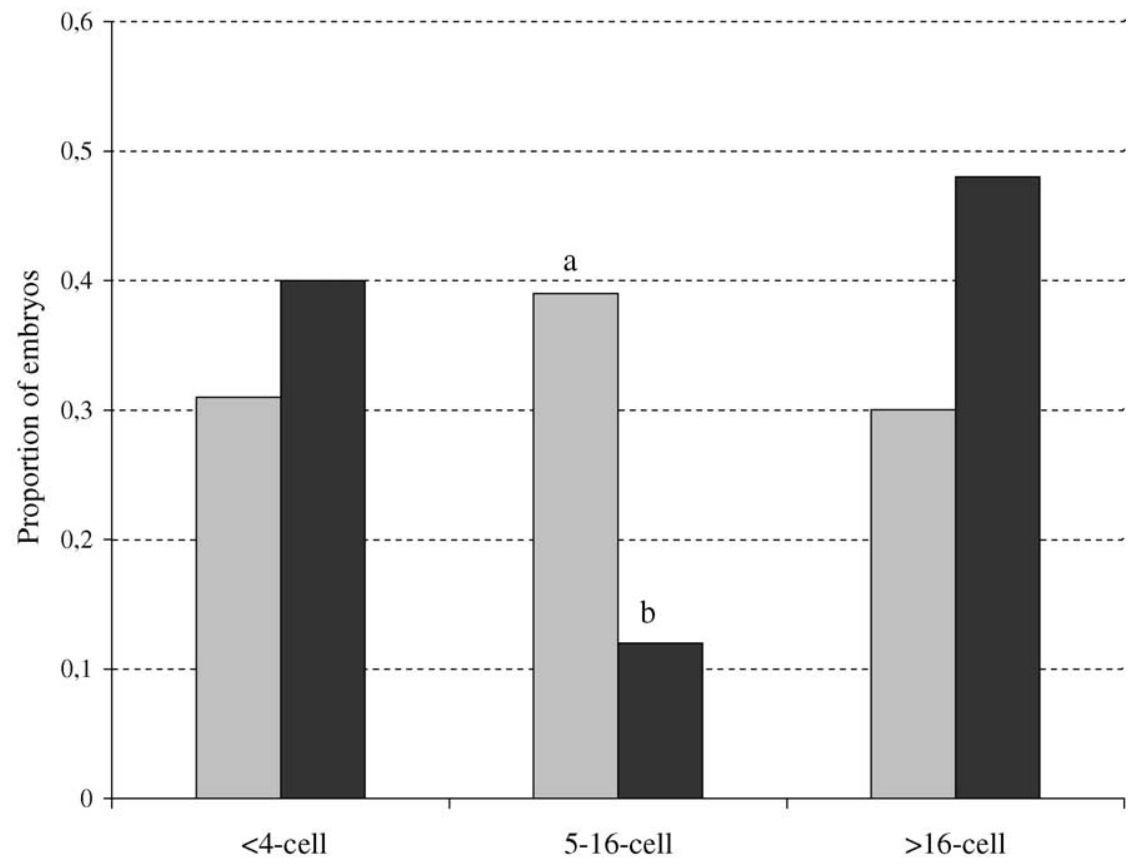

Fig. 4. Proportion of cleaved non-viable embryos according to the developmental stages at which they had stopped developing. Open bars: embryos deriving from follicles $<4 \mathrm{~mm}(n=83)$, solid bars: embryos from follicles $\geq 6 \mathrm{~mm}(n=25)$. Chi-square analysis. $\mathrm{a} \neq \mathrm{b}$ with $P<0.05$.

$(P<0.05)$. Blastocyst rate was $47 \%$ for large follicles against $12 \%$ for small ones $(P<0.001)$.

\subsubsection{Developmental arrest}

Eighty-three embryos from small follicles (56\%) and 25 from large follicles $(38 \%)$ cleaved but stopped developing before the blastocyst stage. Fig. 4 shows at which developmental stages these embryos stopped developing. The distribution is significantly different according to follicles size (Chi-square analysis, $P<0.05)$ with a lower proportion of zygotes from large follicles stopping development between the 5-cell and 16-cell stages, during the third and fourth embryonic cell cycles.

\subsubsection{Cell cycle duration}

The duration of the first embryonic cycles according to the oocyte's follicle size and to the embryo's viability is presented in Fig. 5. Whatever the follicle size, the viable embryos (reaching the blastocyst stage) had a first and a third cell cycle significantly shorter than non-viable embryos $(P<0.05$ for both cell cycles).

If we only focus on blastocysts derived from the two sizes of follicle, the duration of the first three cycles was similar but the duration of the fourth cycle, from 5-8 to 9-16-cell, was shorter for blastocysts derived from large follicles $(29.5 \pm 14 \mathrm{~h}$ versus $38.5 \pm 9 \mathrm{~h})$. The high standard deviation observed here was in fact due to a bimodal distribution of the 


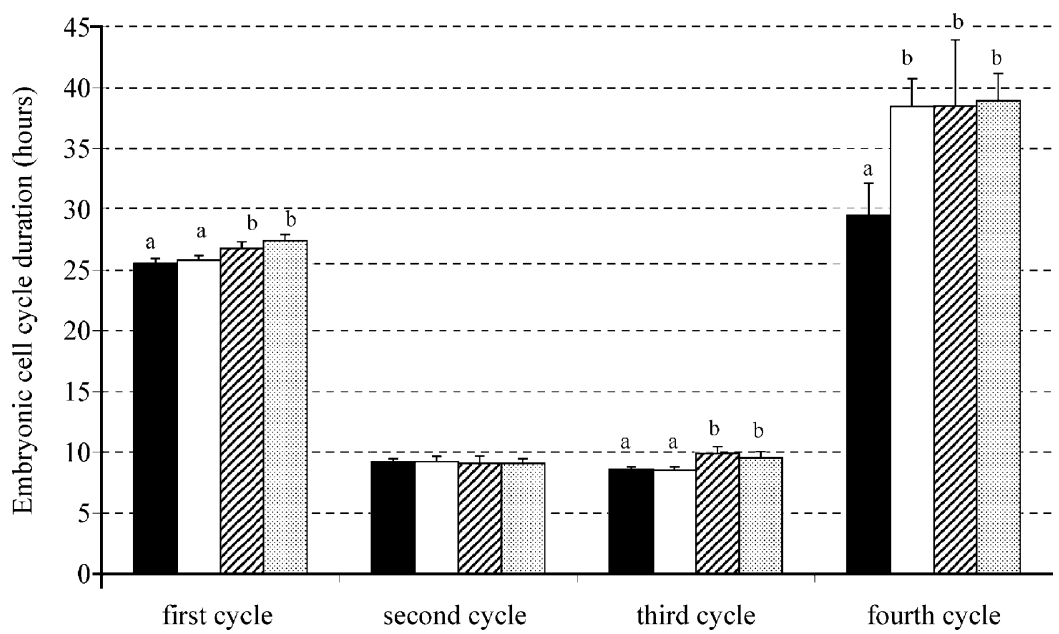

Fig. 5. Duration of the first embryonic cell cycles according to the oocyte follicle size (small $<4 \mathrm{~mm}$ or large $\geq 6 \mathrm{~mm}$ ) and according to the viability of the corresponding embryo. Black bars represent 31 blastocysts from large follicles; open bars: 18 blastocysts from small follicles; hatched bars: 12 non-viable embryos from large follicles and dotted bars: 22 non-viable embryos from small follicles. GLM procedure statistical analysis. a $\neq \mathrm{b}$ with $P<0.05$.

duration of this cycle represented in Fig. 6. Embryos had either a long fourth cell cycle $(>30 \mathrm{~h})$ either a short fourth cell cycle $(<12 \mathrm{~h})$ but no value in between. Twelve blastocysts derived from large follicles $(35 \%)$ had a short fourth cell cycle $(9.7 \pm 1.8 \mathrm{~h})$ but only one $(6 \%)$ coming from small follicles $(P<0.05)$. If we only analysed blastocysts with a long

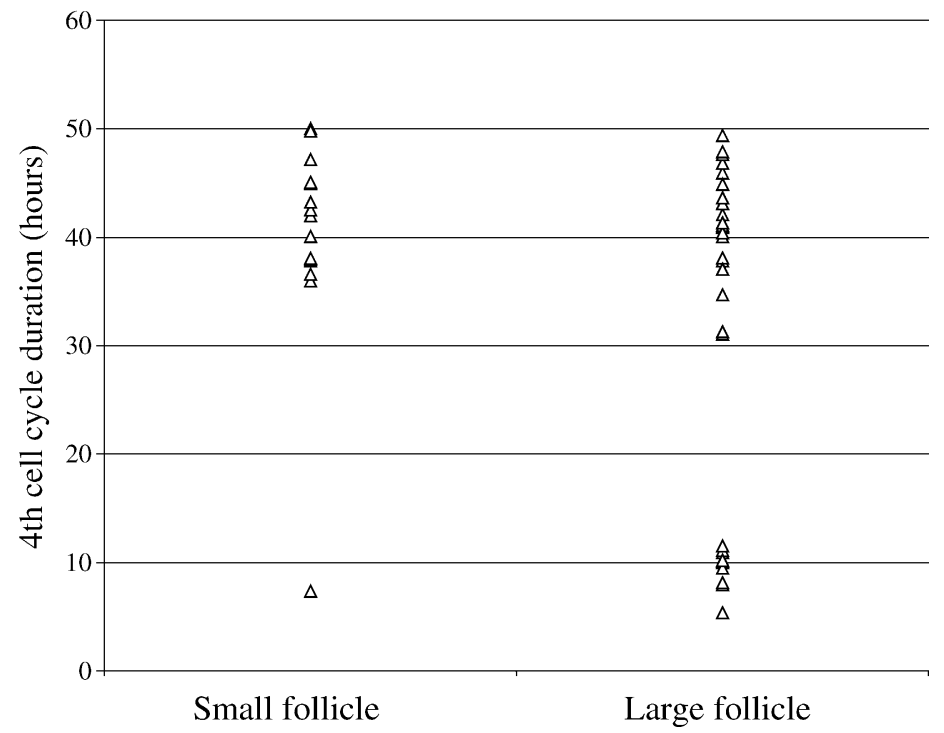

Fig. 6. Distribution of the fourth cell cycle duration (h) according to the oocyte follicle size. Each triangle represents 1 viable embryo, 18 blastocysts from small follicles and 31 from large follicles. 
fourth cell cycle, there was no difference between follicle sizes with $41 \pm 5 \mathrm{~h}$ for the nine blastocysts from large follicles and $43.6 \pm 8 \mathrm{~h}$ for the 17 blastocysts from small follicles.

Finally, cavitation and expansion were delayed when blastocysts derived from small follicles with $157 \mathrm{hpi} \pm 15 \mathrm{~h}(n=18)$ and $169 \mathrm{hpi} \pm 14 \mathrm{~h}(n=13)$ (hpi: hours post insemination \pm S.E.M.) versus $142 \mathrm{hpi} \pm 13 \mathrm{~h}(n=31)$ and $153 \mathrm{hpi} \pm 12 \mathrm{~h}(n=25)$ for blastocyst emerging from large follicles $(P<0.05)$.

\section{Discussion}

The relationship between follicle size and developmental competence has already been described, but follicle classes and results were highly variable. Pavlok et al. [6] did not observe a difference in the developmental competence between oocytes coming from 2 to $4 \mathrm{~mm}$ follicles or from 4 to $8 \mathrm{~mm}$. For Lonergan et al. [7], blastocyst yield from oocytes originating from follicles $>6 \mathrm{~mm}$ was double that of oocytes from 2 to $6 \mathrm{~mm}$. For Blondin and Sirard [8], oocytes derived from follicles $<3 \mathrm{~mm}$ had a lower developmental competence but they could not show differences between 3-5 and $>5 \mathrm{~mm}$, the latter similar to results from Hagemann et al. [10]. In spite of these variable results, it is generally admitted that oocytes from larger follicles have a higher developmental competence than oocytes from smaller ones [29]. This was confirmed in the present study with the three laboratories, where oocytes isolated from follicles with a diameter $\geq 6 \mathrm{~mm}$ consistently had a higher developmental competence than oocytes from follicles $<4 \mathrm{~mm}$. Variable results obtained with the oocytes isolated from 4 to $5 \mathrm{~mm}$ follicles could be related to differences persisting between laboratories such as technical parameters difficult to harmonise between teams. The breed used for oocytes collection and for the semen can be involved too. Reproductive performance are apparently less efficient in animals having double muscle such as BelgianBlue. This could explain a lower developmental rate observed at UCL using Belgian-Blue compared with the developmental rate obtained by the DIAS team using Holsteins.

Cumulus oocyte complex quality according to follicle size was first estimated by analysis of energy metabolism. Cumulus cells play a pivotal role in glucose utilization by the COC, probably by producing pyruvate and lactate, the oocyte's preferred substrates [30]. As a consequence, denuded oocytes have a low ability to incorporate glucose and rely on glutamine and pyruvate for ATP synthesis [31]. In this study, for practical reasons, the metabolism was mainly evaluated on denuded oocytes, not to evaluate the physiological metabolic states, but to compare between oocytes from different follicle sizes. Despite different developmental competence, we could not detect any difference between the metabolism of oocytes from small and large follicles. Few differences were also observed between oocytes collected from prepubertal and adult cows despite a lower developmental competence of calf oocytes [32].

Moreover, we did not observe an important variation when comparing pyruvate metabolism of oocytes at the beginning or at the end of maturation, as reported [31]. Rieger and Loskutoff [33] observed an increase in pyruvate metabolism during the first $12 \mathrm{~h}$ of maturation but, at the end of maturation, the level of pyruvate metabolism was close to what was observed at the beginning of maturation. Oxidative phosphorylation seems to play an important role during oocyte maturation [30] and could, at least partly, be evaluated 
by the measurement of oxygen uptake [14]. To our knowledge, no data were available on the oxygen uptake by oocytes. In this study, oxygen uptake was evaluated at the COC and at the oocyte level. In order to take into account the size of the cumulus, the oxygen uptake by COC was divided by the number of cumulus cells that was on average higher after maturation. No significant difference was observed between follicle classes or between maturation stages. However, oxygen uptake by denuded oocytes was quite low. Two explanations are possible: (1) fully grown oocytes present a low activity of oxidative phosphorylation by comparison with cumulus cells or (2) the removal of cumulus cells affects the level of oxidative phosphorylation in the oocyte despite the availability of pyruvate and glutamine in the medium.

Glycolytic activity can be evaluated by measurement of the production of ${ }^{3} \mathrm{H}_{2} \mathrm{O}$ from 5${ }^{3} \mathrm{H}$ glucose or indirectly from the production of lactate [14]. Using the first technique, Steeves and Gardner [32] observed a progressive increase in glycolytic activity during the $24 \mathrm{~h}$ maturation period, which is in agreement with the increased lactate production found in our study. However, as little glucose is incorporated by denuded oocytes, the production of lactate could derive from endogeneous stores but also from the metabolism of glutamine.

Our cDNA array screening shows, for the first time using a transcriptome scale approach, that the profile of oocyte transcripts, in terms of relative abundances, is globally conserved during the late growth of antral follicle (over $3 \mathrm{~mm}$ ). In fact, none of the detected gene displayed a variation of relative abundance over three folds between oocytes originating from smaller and larger follicles. This is in agreement with previous studies based on radioactive labeling of the nucleoplasm, that have indicated that, whereas oocyte transcriptional activity is extremely intense within the tertiary follicle up until an oocyte diameter of $110 \mu \mathrm{m}$ [34,35], it decreases thereafter to an undetectable level up until shortly before meiosis resumption [36-38]. Our data however do not exclude that rare specific genes, not represented on this array, may be up- or down-regulated in the oocyte during the period considered and affect developmental competence. In fact, putative candidates for differential regulation within the oocyte toward the end of follicle growth were revealed by alternative strategies, considering more extreme follicle classes [39]. It is also possible that qualitative rather than quantitative differences exist between follicle classes, such as the level of polyadenylation that controls stability and translatability. If so, quantitative differences could only appear during in vitro maturation, as the oocyte transcriptome harbours several changes during that process [27] or even later after fertilization.

Protein synthesis is required for meiosis resumption in bovine oocytes [40] with important changes occurring shortly after the germinal vesicle breakdown [15,37] but also later [41]. Although the protein pattern changed during maturation, no obvious difference between follicle sizes could be evidenced, except a higher intensity of staining for oocytes from large follicles. Variations below the sensibility of our experimental procedure cannot be excluded. Changes could also appear at a time point during the maturation process not analysed here or variable developmental competence might be due to differences in protein content acquired before the maturation process.

The kinetics of meiosis resumption may indicate the ability of oocytes to develop further as oocytes extruding the first polar body earlier were shown to cleave earlier into two-cell and give a higher blastocyst rate [17]. Here we looked for a correlation between the kinetics of maturation and the follicle sizes but no significant difference was demonstrated at any of 
the meiotic stages and progression through meiosis respects the timing described by others $[41,42]$. However, a recent study [43] demonstrated that oocytes from 4 to $5 \mathrm{~mm}$ follicles required slightly more time to reach anaphase I than those from 2 to $3 \mathrm{~mm}$ follicles. Maybe differences in the quality of the COC could explain this discrepancy as quality influences progression though meiosis. Indeed, COCs with signs of atresia resume meiosis faster than other ones [44]. Surrounding granulosa cells also seem to influence the kinetics of maturation with a faster resumption of meiosis when oocytes are denuded [45]. In this study, we observed that small follicles contain a higher proportion of poor quality COCs with a low number of layers of cumulus cells (see metabolism data), these cumulus cells are frequently expanded and the cytoplasm of the oocyte is often granulated. So, depending on the selection of the COCs, variable results could be obtained.

After fertilization, the cleavage pattern is a parameter of embryonic quality. The timing of the first cleavage but also cleavage asynchrony or blastomeres fragmentation can be predictive of embryonic competence [21]. In the present study, embryos derived from small follicles stopped cleaving more frequently during the third and fourth embryonic cell cycles leading to unevenly sized blastomeres. Chromosomal aberration is one cause of early development arrest $[46,47]$ but the oocytes from both follicle sizes are all fully-grown so the frequency of chromosomal aberrations should be similar [48]. Maternal inherited cytoplasm may also interfere with cell cycle kinetics. Maternal molecules stored in oocytes from small follicles could be insufficient or not adequately processed to assure a correct development before the transition from maternal to zygotic control of development (MZT) that only occurs during the fourth cell cycle in the bovine [49].

As already reported [21], viable embryos had a shorter duration of the first and third embryonic cycles than non-viable embryos, whatever the follicle size. When blastocysts were derived from large follicles, a higher proportion of them had a rapid transition between the 5-8 and 9-16-cell stages with a fourth cycle lasting $9 \mathrm{~h}$ as the second and third cycles. During the first embryonic cycles, gap phases (G1 and G2) are reduced or even absent but they would appear, in the bovine embryo, during the long fourth cycle concomitantly with the major onset of zygotic transcription [50]. However, if transcription is inhibited, the fourth cell cycle is always short [51]. The duration of the fourth cycle could depend on the exact timing for the major resumption of embryonic transcription which, in turn, could depend on the amount and quality of maternal molecules stored in the oocytes during growth and maturation. Thus, some oocytes from large follicles may have a cytoplasmic content able to report the burst of embryonic transcription, and the appearance of gap phases, during one more cycle. So, not only oocytes from large follicles gave a higher blastocyst rate, but also more of these blastocysts had a short fourth cell cycle. However, it is not known if blastocysts characterised by a short fourth cell cycle have a higher quality, indeed they do not have a higher number of cells [51]. The timing of cavitation is one indicator of blastocyst quality. Early appearing blastocysts have a higher number of cells [18], a better resistance to cryopreservation and they give higher pregnancy rates [52]. Here, blastocysts emerging from small follicles presented a delayed cavitation maybe due to a lower embryonic quality, however their total cell number was not affected. A possible so-called "group effect" should not be neglected either: embryos secrete embryotrophic factors [53] able to stimulate the development of the other embryos [54]. Thus, a delayed cavitation observed for blastocysts derived from small follicles could be 
due to their low number among each culture drop compared with the numerous blastocysts coming from large follicles. Some oocyte cytoplasmic deficiency cannot be excluded either.

In conclusion, three laboratories confirmed that oocytes derived from follicles with a diameter $\geq 6 \mathrm{~mm}$ have a higher developmental competence than oocytes from follicles $<4 \mathrm{~mm}$. However, at the oocyte level, none of the parameters investigated, energy metabolism, gene expression profile, neosynthesis protein pattern or kinetics of meiotic resumption were different between follicle sizes. At the embryo level, more blastocysts derived from large follicle had a short fourth cell cycle whereas blastocysts from small follicles exhibited a delayed cavitation and expansion. Although it could not be demonstrated here, these embryonic events may be related to differences in molecule storage or to variable tuning of the molecular program within the corresponding oocytes.

\section{Acknowledgements}

This work was funded by the European Commission, Grant EU number QLK3-CT199900104 (Vth Framework). The excellent technical assistance of Ruth Kristensen, Anette Pedersen, Susanne Bøhrk, Klaus Villemoes (Denmark), Joëlle Marchandise, André Moens, Isabelle Simonis, Benjamin Verhaeghe (Belgium), Florence Guignot, Allan King, Yann Locatelli, Christine Perreau, Nati Poulin (France) is greatly appreciated.

\section{References}

[1] Gordon I. Transferring embryos and establishing pregnancies. In: Persley J, editor. Laboratory production of cattle embryos, 2nd ed. Oxon: CAB International; 2003. p. 329-54.

[2] Rizos D, Ward F, Duffy P, Boland MP, Lonergan P. Consequences of bovine oocyte maturation, fertilization or early embryo development in vitro versus in vivo: implications for blastocyst yield and blastocyst quality. Mol Reprod Dev 2002;61:234-48.

[3] Gandolfi F, Luciano AM, Modina S, Ponzini A, Pocar P, Armstrong DT, et al. The in vitro developmental competence of bovine oocytes can be related to the morphology of the ovary. Theriogenology 1997;48:1153-60.

[4] Varisanga MD, Sumantri C, Murakami M, Fahrudin M, Suzuki T. Morphological classification of the ovaries in relation to the subsequent oocyte quality for IVF-produced bovine embryos. Theriogenology 1998;50:1015-23.

[5] Machatkova M, Jokesova E, Horky F, Krepelova A. Utilization of the growth phase of the first follicular wave for bovine oocyte collection improves blastocyst production. Theriogenology 2000;54:543-50.

[6] Pavlok A, Lucas-Hahn A, Niemann H. Fertilization and developmental competence of bovine oocytes derived from different categories of antral follicles. Mol Reprod Dev 1992;31:63-7.

[7] Lonergan P, Monaghan P, Rizos D, Boland MP, Gordon I. Effect of follicle size on bovine oocyte quality and developmental competence following maturation, fertilization, and culture in vitro. Mol Reprod Dev 1994;37:48-53.

[8] Blondin P, Sirard MA. Oocyte and follicular morphology as determining characteristics for developmental competence in bovine oocytes. Mol Reprod Dev 1995;41:54-62.

[9] de Wit AA, Kruip TA. Bovine cumulus-oocyte-complex-quality is reflected in sensitivity for alphaamanitin, oocyte-diameter and developmental capacity. Anim Reprod Sci 2001;65:51-65.

[10] Hagemann L, Beaumont S, Berg M, Donnison M, Ledgard A, Peterson A, et al. Development during single IVP of bovine oocytes from dissected follicles: interactive effects of estrous cycle stage, follicle size and atresia. Mol Reprod Dev 1999;53:451-8. 
[11] Hazeleger NL, Hill DJ, Stubbing RB, Walton JS. Relationship of morphology and follicular fluid environment of bovine oocyte to their developmental potential in vitro. Theriogenology 1995;43:509_ 22.

[12] Boni R, Cuomo A, Tosti E. Developmental potential in bovine oocytes is related to cumulus-oocyte complex grade, calcium current activity, and calcium stores. Biol Reprod 2002;66:836-42.

[13] Laurincik J, Hyttel P, Baran V, Schmoll F, Niemann H, Brem G, et al. Corona radiata density as a noninvasive marker of bovine cumulus-corona-complexes selected for in vitro embryo production. Theriogenology 1996;46:369-77.

[14] Donnay I. Metabolic markers of embryo quality. In: Van Soom A, Boerjan M, editors. Assessment of mammalian embryo quality. Dordrecht: Kluwer Academic Publishers; 2002; Chapter 3, p. 57-94.

[15] Kastrop PM, Bevers MM, Destree OH, Kruip TA. Changes in protein synthesis and phosphorylation patterns during bovine oocyte maturation in vitro. J Reprod Fertil 1990;90:305-10.

[16] Kastrop PM, Bevers MM, Destree OH, Kruip TA. Analysis of protein synthesis in morphologically classified bovine follicular oocytes before and after maturation in vitro. Mol Reprod Dev 1990;26:222-6.

[17] Dominko T, First NL. Timing of meiotic progression in bovine oocytes and its effect on early embryo development. Mol Reprod Dev 1997;47:456-67.

[18] Van Soom A, Ysebaert MT, de Kruif A. Relationship between timing of development, morula morphology, and cell allocation to inner cell mass and trophectoderm in in vitro-produced bovine embryos. Mol Reprod Dev 1997;47:47-56.

[19] Grisart B, Massip A, Dessy F. Cinematographic analysis of bovine embryo development in serum-free oviduct-conditioned medium. J Reprod Fertil 1994;101:257-64.

[20] Holm P, Shukri NN, Vajta G, Booth P, Bendixen C, Callesen H. Developmental kinetics of the first cell cycles of bovine in vitro produced embryos in relation to their in vitro viability and sex. Theriogenology 1998;50:1285-99.

[21] Holm P, Booth PJ, Callesen H. Kinetics of early in vitro development of bovine in vivo- and in vitroderived zygotes produced and/or cultured in chemically defined or serum-containing media. Reproduction 2002;123:553-65.

[22] Holm P, Booth PJ, Schmidt MH, Greve T, Callesen H. High bovine blastocyst development in a static in vitro production system using SOFaa medium supplemented with sodium citrate and myo-inositol with or without serum-proteins. Theriogenology 1999;52:683-700.

[23] Houghton FD, Thompson JG, Kennedy CJ, Leese HJ. Oxygen consumption and energy metabolism of the early mouse embryo. Mol Reprod Dev 1996;44:476-85.

[24] Leese HJ, Barton AM. Pyruvate and glucose uptake by mouse ova and preimplantation embryos. J Reprod Fertil 1984;72:9-13.

[25] Laemmli UK. Cleavage of structural proteins during the assembly of the head of bacteriophage T4. Nature 1970;277:680-5.

[26] Motlik J, Koefoed-Johnsen HH, Fulka J. Breakdown of the germinal vesicle in bovine oocytes cultivated in vitro. J Exp Zool 1978;205:377-83.

[27] Dalbiès-Tran R, Mermillod P. Use of heterologous complementary DNA array screening to analyze bovine oocyte transcriptome and its evolution during in vitro maturation. Biol Reprod 2003;68:252-61.

[28] SAS (R) Technical Report P-243. SAS/STAT Software, release 6.09. Cary, NC; p. 88.

[29] Hendriksen PJ, Vos PL, Steenweg WNM, Bevers MM, Dielemans SJ. Bovine follicular development and its effect on the in vitro competence of oocytes. Theriogenology 2000;53:11-20.

[30] Sutton ML, Gilchrist RB, Thompson JG. Effects of in-vivo and in-vitro environments on the metabolism of the cumulus-oocyte complex and its influence on oocyte developmental capacity. Hum Reprod Update 2003;9:35-48.

[31] Zuelke KA, Brackett BG. Effects of luteinizing hormone on glucose metabolism in cumulus-enclosed bovine oocytes matured in vitro. Endocrinology 1992;131:2690-6.

[32] Steeves T, Gardner DK. Metabolism of glucose, pyruvate, and glutamine during the maturation of oocytes derived from pre-pubertal and adult cows. Mol Reprod Dev 1999;54:92-101.

[33] Rieger D, Loskutoff NM. Changes in the metabolism of glucose, pyruvate, glutamine and glycine during maturation of cattle oocytes in vitro. J Reprod Fertil 1994;100:257-62.

[34] Crozet N, Kanka J, Motlik J, Fulka F. Nucleolar fine structure and RNA synthesis in bovine oocytes from antral follicles. Gamete Res 1986;14:65-73. 
[35] Fair T, Hyttel P, Greve T, Boland M. Nucleus structure and transcriptional activity in relation to oocyte diameter in cattle. Mol Reprod Dev 1996;43:503-12.

[36] Kastrop PM, Hulshof SC, Bevers MM, Destree OH, Kruip TA. The effects of alpha-amanitin and cycloheximide on nuclear progression, protein synthesis and phosphorylation during bovine oocyte maturation in vitro. Mol Reprod Dev 1991;28:249-54.

[37] Memili E, Dominko T, First NL. Onset of transcription in bovine oocytes and preimplantation embryos. Mol Reprod Dev 1998;51:36-41.

[38] Tomek W, Torner H, Kanitz W. Comparative analysis of protein synthesis, transcription and cytoplasmic polyadenylation of mRNA during maturation of bovine oocytes in vitro. Reprod Dom Anim 2002;37:8691.

[39] Robert C, Barnes FL, Hue I, Sirard MA. Subtractive hybridization used to identify mRNA associated with the maturation of bovine oocytes. Mol Reprod Dev 2000;57:167-75.

[40] Hunter AG, Moor RM. Stage-dependent effects of inhibiting ribonucleic acids and protein synthesis on meiotic maturation of bovine oocytes in vitro. J Dairy Sci 1987;70:1646-51.

[41] Sirard MA, Florman HM, Leibfried-Rutledge ML, Barnes FL, Sims ML, First NL. Timing of nuclear progression and protein synthesis necessary for meiotic maturation of bovine oocytes. Biol Reprod 1989;40:1257-63.

[42] Wehrend A, Meinecke B. Kinetics of meiotic progression, M-phase promoting factor (MPF) and mitogenactivated protein kinase (MAP kinase) activities during in vitro maturation of porcine and bovine oocytes: species specific differences in the length of the meiotic stages. Anim Reprod Sci 2001;66:175-84.

[43] Torner H, Kubelka M, Heleil B, Tomek W, Aim H, Kuzmina T, et al. Dynamics of meiosis and protein kinase activities in bovine oocytes correlated to prolactin treatment and follicle size. Theriogenology 2001;55:885-99.

[44] Mayes MA, Sirard MA. The influence of cumulus-oocyte complex morphology and meiotic inhibitors on the kinetics of nuclear maturation in cattle. Theriogenology 2001;55:911-22.

[45] Fissore RA, He CL, Vande Woude GF. Potential role of mitogen-activated protein kinase during meiosis resumption in bovine oocytes. Biol Reprod 1996;55:1261-70.

[46] Kawarsky SJ, Basrur PK, Stubbings RB, Hansen PJ, King WA. Chromosomal abnormalities in bovine embryos and their influence on development. Biol Reprod 1996;54:53-9.

[47] Viuff D, Greve T, Avery B, Hyttel P, Brockhoff PB, Thomsen PD. Chromosome aberrations in in vitroproduced bovine embryos at days 2-5 post-insemination. Biol Reprod 2000;63:1143-8.

[48] Lechniak D, Kaczmarek D, Stanislawski D, Adamowicz T. The ploidy of in vitro matured bovine oocytes is related to the diameter. Theriogenology 2002;57:1303-8.

[49] Telford NA, Watson AJ, Schultz GA. Transition from maternal to embryonic control in early mammalian development: a comparison of several species. Mol Reprod Dev 1990;26:90-100.

[50] Barnes FL, Eyestone W. Early cleavage and maternal zygotic transition in bovine embryos. Theriogenology 1990;33:141-53.

[51] Lequarre AS, Marchandise J, Moreau B, Massip A, Donnay I. Cell cycle duration at the time of maternal zygotic transition for in vitro produced bovine embryos: effect of oxygen tension and transcription inhibition. Biol Reprod 2003;69:1707-13.

[52] Hasler JF, Henderson W, Hurtgen P, Jin ZQ, McCauley A, Mower S, et al. Production, freezing and transfer of bovine IVF embryos and subsequent calving results. Theriogenology 1995;43:141-52.

[53] Thibodeaux JK, Godke RA. Potential use of embryo coculture with human in vitro fertilization procedures. J Assist Reprod Genet 1995;12:665-77.

[54] Larson MA, Kubisch HM. The effects of group size on development and interferon-tau secretion by invitro fertilized and cultured bovine blastocysts. Hum Reprod 1999;14:2075-9. 